\title{
Lumen
}

Selected Proceedings from the Canadian Society for Eighteenth-Century Studies

\section{Talking to the Margins: Lady Mary Wortley Montagu at the Nadir Of Communication}

\section{Isobel Grundy}

Volume 28, 2009

URI : https://id.erudit.org/iderudit/1012041ar

DOI : https://doi.org/10.7202/1012041ar

Aller au sommaire du numéro

Éditeur(s)

Canadian Society for Eighteenth-Century Studies / Société canadienne d'étude du dix-huitième siècle

ISSN

1209-3696 (imprimé)

1927-8284 (numérique)

Découvrir la revue

Citer cet article

Grundy, I. (2009). Talking to the Margins: Lady Mary Wortley Montagu at the Nadir Of Communication. Lumen, 28, 111-125.

https://doi.org/10.7202/1012041ar

Copyright (C Canadian Society for Eighteenth-Century Studies / Sociéte canadienne d'étude du dix-huitième siècle, 2009
Ce document est protégé par la loi sur le droit d'auteur. L'utilisation des services d'Érudit (y compris la reproduction) est assujettie à sa politique d'utilisation que vous pouvez consulter en ligne.

https://apropos.erudit.org/fr/usagers/politique-dutilisation/ 


\section{7: Talking to the Margins: Lady Mary Wortley Montagu at the Nadir Of Communication}

Communication is powerful: in 2006 a number of scholars including myself published online, with Cambridge University Press, Orlando: Women's Writing in the British Isles from the Beginnings to the Present. ${ }^{1}$ Electronic communication being independent of the time-zones, this text, with all its information about Lady Mary Wortley Montagu is open to readers worldwide, day or night. Communication is still fragile - systems go down - but nothing like so fragile as it used to be. This article discusses something that Montagu produced in privacy and isolation as if despairing of communication either written or spoken - and something so peripheral that it is not covered in the Orlando textbase. She annotated, with comments up and down its margins, a standard text on the highly patriarchal topic of heraldry.

To Google Montagu in fall 2007 would have brought 173,000 hits, with Wikipedia standing first. (While perhaps no more error-ridden than other sources the Wikipedia entry does make its first mistake in its opening sentence.) Today Montagu enjoys celebrity as well as literary fame; she is an object as well as a subject of communication. Yet when she wrote the notes discussed here - notes in a most unlikely book - she apparently had no intended audience. The exact dating of these marginal annotations cannot be pinned down, but they almost certainly belong to the decade 1746 to 1756 . It's true that one anecdote among the annotations sounds as if it were written in the early eighteenth

1 Susan Brown, Patricia Clements, and Isobel Grundy, eds., Orlando: Women's Writing in the British Isles from the Beginnings to the Present (Cambridge: Cambridge University Press online, 2006- ), by subscription. 
century, ${ }^{2}$ and another might refer to a scandal that happened in February 1762, when Lady Mary had just returned to England with advanced breast cancer, and with only seven months to live. ${ }^{3}$ But almost certainly she annotated the book in question between 1746 and 1756, while she was almost incommunicado in remote North Italy, with no outlet for publishing, little hope of letters getting through, and not even Englishspeakers with whom to communicate. The isolation reflected here is that of an exile in a distant clime, rather than that of a revenante from the past in a London which had all but forgotten her.

During that decade, Lady Mary was invisible to English society, and widely assumed to be dead. In the absence of society and communication she still filled her time with words. She worked on fiction (including the astonishing novella-length piece which is now titled "Princess Docile" and published in the volume titled her Romance Writings), and on the "History of my Own Times," which she says, she burned in instalments as she finished them, ${ }^{5}$ on her commonplace-book, and presumably on the diary which her daughter later burned. She kept writing letters, some of which survive. Each of these kinds of writing was an assertion of her continuing, complex identity, and so, in this respect her notes on the topic of heraldry were no different.

Enumerating Lady Mary's North Italian writings is a tribute to lost writing - in general - to those many, many vanished works (especially though not exclusively by women) whose loss is to be mourned; it is also a tribute to Montagu, a reminder, though perhaps not necessary today, of her literary stature. This paper deals with comparative trivia, with mere jottings whose loss would have been no disaster.

2 She writes: "still remains ye Heiresse of ye Cheife Branch [of the Wray family] Cousin german to my Father a melancholy Widow of a Bad Husband Mr Saunderson Son \& Heir to Ld Castleton." (228) But this relation, born Sarah Evelyn of West Dean, whose third husband did himself become Lord Castleton, died in 1717 (GEC), so there must be some confusion.

3 She implies that Lord Pembroke is mad, and since her contemporary Lord Pembroke was thought crazy by some (GEC), it is not necessary to suppose that she is referring to the elopement of his son and successor in February 1762, although this elopement was something that she later took an interest in. (His escapade is the subject of the last item transcribed in her Harrowby MS 255, a couplet apparently written by Horace Walpole.)

4 Lady Mary Wortley Montagu, Romance Writings, ed. Isobel Grundy (Oxford: Clarendon Press, 1996).

5 Isobel Grundy, Lady Mary Wortley Montagu, Comet of the Enlightenment (Oxford: Clarendon Press, 1999), 529-30. 
Heather Jackson's fine book Marginalia has alerted us to the importance of this form of literary expression: it is significant not in itself but as a window into the author's mind. When she made the marginal annotations under examination here Lady Mary was presumably bored, though scribbling in books was one of her habits. In contemporary novels her comments in the margins range from "foolish" and "good for nothing" through "smart tho ordinary" to the famous "ne plus ultra" in a copy of Tom Jones. In an early seventeenth-century Italian romance she wrote, "Beautifull in her Old Fashion'd Dress." ${ }^{8}$ These must have been late-life marginalia; they are very unlike the passionate argument which long before Mary Astell had poured out, with the "just Indignation" of a "Lover of Truth", all over the flyleaf and down the margins of a book belonging to Lady Mary and written by Pierre Bayle. ${ }^{9}$

But Lady Mary must have been bored to attack the margins of a book not of literature or polemic but of heraldry. This handsome folio volume bills itself as the fourth edition of A Display of Heraldry: Manifesting a more easie access to the knowledge thereof then hath hitherto been published by any, through the benefit of Method, by "John Guillim, late Pursuivant at Armes." Guillim had first published this definitive reference work in 1610 and had died in 1621, but new editions kept on being printed and the work became an institution, like Burke's Peerage two centuries later. Montagu's copy of the fourth edition, 1660, is a later impression of that edition, issued after the Restoration in May of that year. The version of the fourth edition shown in EEBO, "Faithfully collected by Francis Nower, Arms-Painter (and student in Heraldry)" ${ }^{10}$ clearly pre-dates the Restoration of Charles II, and it needed to be hastily revised, as is explained in the last paragraph of the densely informative title-page of Montagu's copy (Figure 1): "And since the imprinting of this last Edition many offensive Coats (to the Loyal Party) are exploded." The Civil War and Interregnum had set its mark on the system of nobility and on

6 Harrowby Manuscripts Trust, Sandon Hall, Staffordshire. Harrowby MS 139.

7 Isobel Grundy, "Books and the Woman: An Eighteenth-Century Owner and her Libraries", English Studies in Canada, 20: 1 (March 1994), 6.

8 Harrowby MS 139.

9 Grundy, 193-4.

10 John Guillim, A Display of Heraldry: Manifesting a more easie access to the knowledge thereof then hath hitherto been published by any, through the benefit of Method, fourth edition (London: Jacob Blome, 1660), title-page. 
the reference work "Guillim", but by late 1660 the monarchy had been safely restored and heraldry was back to business as usual. Montagu's copy offers "a Supply of His Majesties Friends ... . Together with the Atchievements at large of most of the Nobility which have been made by King CHARLES the Second." ${ }^{\prime 11}$

As Figure 1 shows, no owner of this copy had set their name on the title-page until, down at the bottom, Lady Mary wrote the simplest of her various marks of ownership: the single capital letter " $M$ ".

Figure 2 shows the preliminary address (almost a dedication) "To the Most Concern'd, The Nobility and Gentry," a further expression of regret over Guillim's recent "Blot in its Escocheon, viz. The insertion of Oliver's Creatures; which as no merit could enter them in such a Regiment but Usurpation, so we have in this fifth Impression exploded them, and inserted the Persons, Titles, and Dignities of such, as his Majestie (since his blessed Restauration) conferred Honour upon; that so the Corn may be intire, of one Sheaf, and the Grapes of one Vine." This must have been an interim measure, before a dedication to the new king could be arranged for the fifth edition, 1664, and the Nobility and Gentry address was bumped several places back in the file of compliments. Meanwhile, Montagu wrote beside it: "Slavery worthy a Printer." This is her first expression of opinion here: anti-courtier, but also anti-printer.

The element of opposition or resistance stands at the heart of most of her finest writing, and it animates these annotations too. Heraldry was a topic which, for class reasons and because of its close connection with history and especially family history, Montagu might be expected to be well versed in. But it is a patriarchal, hierarchical, antique, and arbitrary system of knowledge, its symbols representative of many institutions which she had opposed for all of her life. Her annotations assert her identity as both woman and aristocrat, both proto-feminist and Old Whig.

The patriarchalism of heraldry is woven into its own history. Coats of arms derive from the insignia traditionally carried by knights in battle, like the numbers on hockey players or the colours on jockeys, to ensure recognition by fellow-combatants in warfare and by spectators in jousting. Coats of arms signified both the family and its current male representative. Women might be proud of their birth family and coat of arms, but their own relation with this badge of honour consisted in their duty to quarter it (that is, make it share a single shield) 


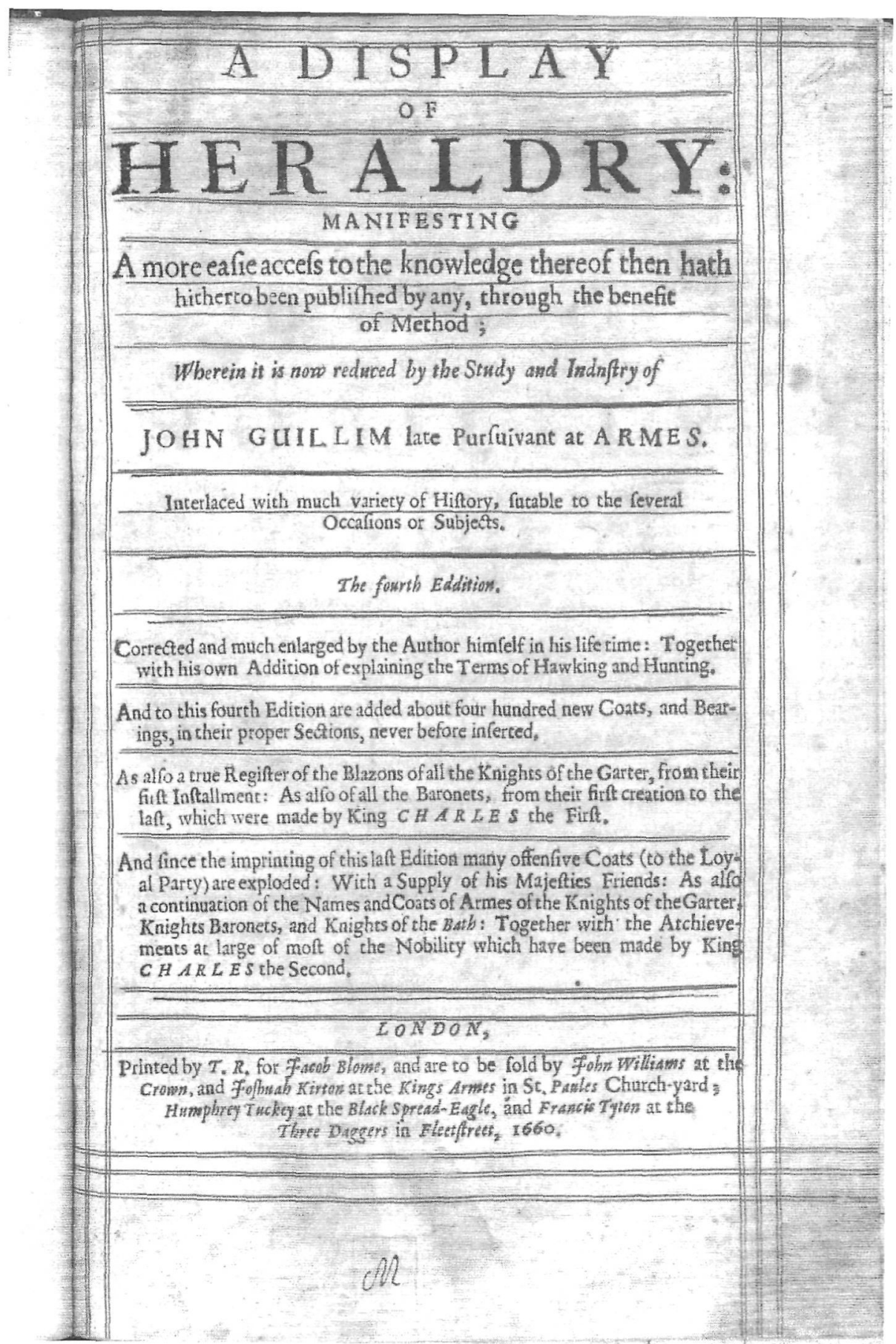

Figure 1 


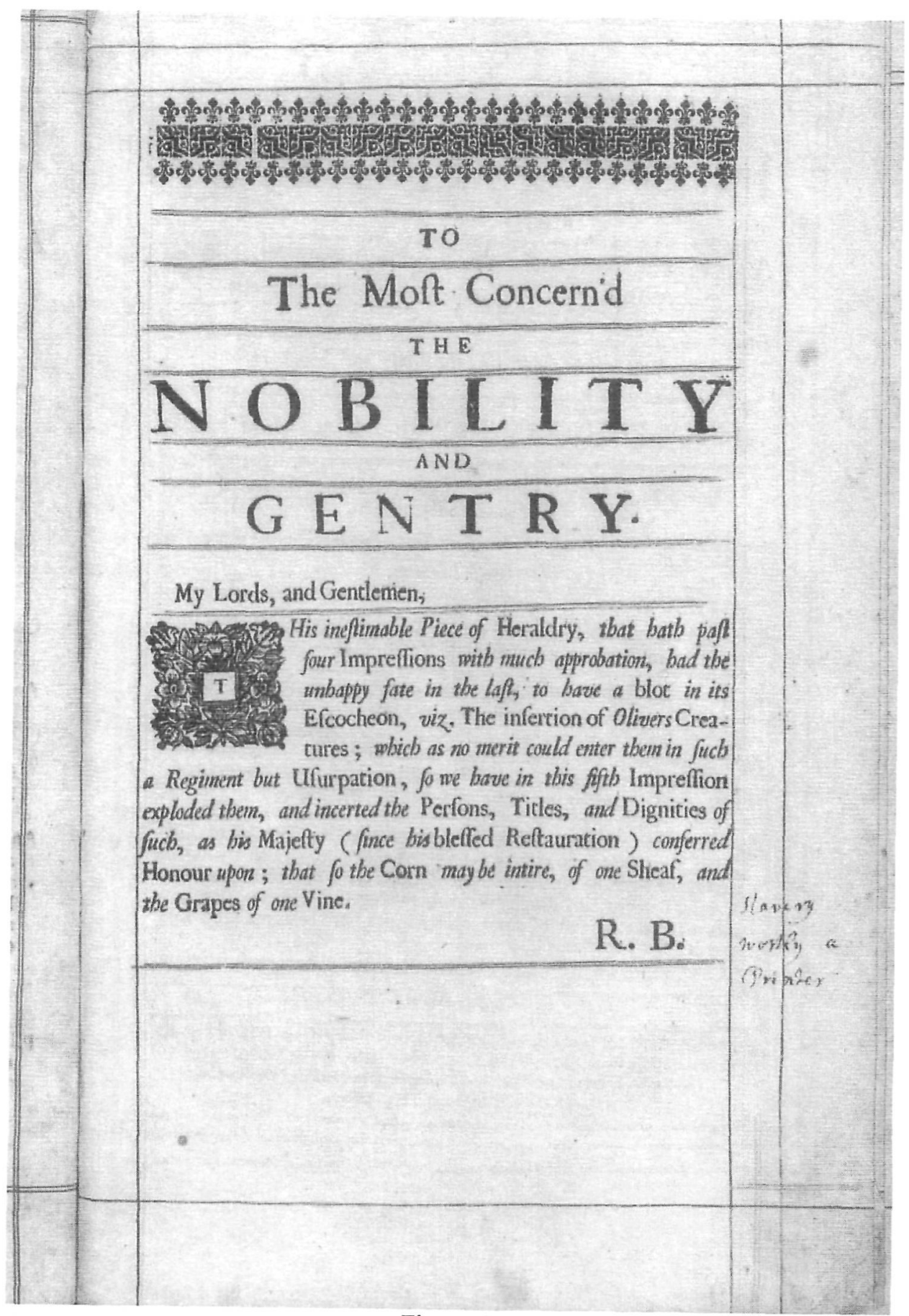

Figure 2 
with that of their husband's family. For a woman, heraldry marked and rendered visible her function as a channel of power from one male to another.

It was a royalist system, a system reflecting hereditary privilege. Honours flowed from the king; heralds were outraged at the reign of "Oliver". Heraldry, though it also records achievement, is chiefly concerned with enforcing the hierarchy of primogeniture. It was also an ancient system: Montagu's copy of Guillim is full of animal lore that might have come straight from a medieval bestiary, and full too of a kind of recherché folk belief at odds with the newer learning patronised by the Royal Society.

Montagu, on the other hand, was, in modern terminology, a feminist. She perceived, analysed, and resented the way that women of her class were excluded from the power wielded by their male counterparts, and the way that their freedom of action and of thought was circumscribed by gender convention. She hated the custom of primogeniture because of the way it stifled talent and failed to reward merit. She was a woman of the Enlightenment, a moderniser who looked for improvements and looked askance on custom and the old ways generally. In politics she was an Old Whig, something which was hard to define in the eighteenth century but which in the seventeenth century had signified a resister of monarchical power, a parliamentarian if not a Cromwellian. Her status and opinions set her at odds with Guillim, and she seems to have chosen to annotate the book as a form of response or refutation. Yet it is an odd form of protest to choose. Her annotations remained hidden (undiscovered, indeed, until the late 1990s), unlike a published response (a form which Montagu had made her own both in prose and verse). Indeed, by forming part of the volume annotated, her comments seem to submerge their authority within it, acting like the updating of a reference work to strengthen rather than undermine it.

To describe Lady Mary's annotations properly I must first describe the text in which we find them. After Guillim's large bouquet of paratexts comes a general introduction to heraldry, its origins and development. The general introduction is followed by an exhaustive listing of all the parts that may make up a coat of arms: first the colours (including those representing precious metals), backgrounds (mostly representing different kinds of furs), and bordures or borders; then the different houses into which the shield is divided; and finally all the objects used in heraldry: common natural objects like suns, stars, lions, leopards, and lilies, less common natural objects such as scorpions, sheaves of wheat and turnips, and man-made objects like mitres and tassels. Guillim gives examples and sketches of all of these in use, and says what 
family they belong to. Beside his picture of a shield bearing "A Turnip, proper," Montagu wrote, "I love Turnips \& thank G[od] for them." ${ }^{12}$

A later section treats the arms of British royalty and high nobility in more detail, showing the shield, quartered appropriately for the current bearer, with its supporters, crest, motto, etc. Montagu however, gave up annotating well before she reached these splendid full-page illustrations. After a penultimate marginal note about the Evelyns (her paternal grandmother's family) on page 258 , she remained silent but for one further note: next to the very impressive, large-size rendering of the Pierrepont coat of arms (as borne by her ancestor Henry Marquess of Dorchester, with lions for supporters and a heavy-whiskered, shifty-looking fox as the crest), she wrote: "my Family", and filled in on the shield itself a couple of the names of related families. These are her last marks in the book, in which she wrote on 78 of its more than 500 pages. $^{13}$

The annotations themselves exemplify an Enlightenment response to Renaissance learning, a feminist response to patriarchy, an Old Whig's response to Stuart loyalism, a Deist's response to orthodox Christianity, an old person's nostalgia, and just possibly a woman writer's solidarity with her sisters. Lady Mary begins in that spirit of irritated superiority that drives so many of us to mark the pages of books. Expounding on the fundamentals of heraldry in the general introduction Guillim enters into a dispute with other commentators. Montagu's first comment in the body of the book - "A Great Author" - might refer sarcastically either to Guillam or to his current antagonist, one Chassaneus. There is no doubt about her next comment: when Guillim deplores the way "the French Armorists for the most part doe blazon the Charge first, and the Field after, which is a course meerly repugnant to Nature," Montagu weighs in with, "fy naughty French" ${ }^{14}$ - mocking Guillim's opinion by making it petty and foolish. She must have enjoyed her own comment because she later re-used it. I shall not enumerate here all of her sarcasms along the lines of "Oh rare!" (16), "wonderfull Discovery!" (17), or "a great scholar god knows" (19). When Guillim informs his readers that serpents take special care to defend their heads, as being

12 Guillim, Montagu's copy, 152. Later references given in text.

13 That is, if the owners indeed most generously sent me, as they said they had, copies of every page that bears her marks.

14 Apparently page 18: photocopy imperfect. When her annotations have no page cited this reflects the same flaw in the copying. 
their weakest parts, she writes: "men never find out their heads are weak" (211).

Most of her comments are classifiable as either scientific, political, family-related, gender-related, or some combination of these. On the page after Montagu's first "fy naughty French", Guillim sets out to explain colour. "Colour, may be said to be an externall die, wherewith any thing is coloured or stained, or else it may be said to be the glosse of a body beautified with light." She comments, "never read Newton alas; he was not born poor Guillim." When Guillim mentions fixed stars she briskly corrects him: "now Suns". When he writes about a point of precedence being settled by single combat she exclaims, "a true church Decision. Miracle! Miracle!" (36). She is not happy with the Biblical tradition of using "fat" to signify desirable, or "waxing fat" as being pampered, and responds: "Fat no such Blessing in these ages, witness Cecils ${ }^{15}$ and Wallops" (78), and again, 150 pages further on: "Q[uery] is it a blessing to be fat?" (229). At a mention of "Guy Earle of Warwick, who was Champion for King Athelstan," she responds: "I am afraid was never born" (85). When Guillim confidently sets a divide between "unreasonable [creatures], such are Animals" and "Reasonable, which is Man," she writes "Vain Man!" (95). When he asserts that "four footed Egg-bearing Animals" are comparatively lacking in "quicknesse of wit," she observes mildly, "we are not so well acquainted wth them" (205).

Yet while she pours scorn on superstition, she is happy to find Guillim making statements she can accept. When he notes that in all ages kings and emperors have chosen table vessels made of silver, she adds "a fashion to this Day" (17). When he says the Athenians used to wear golden grasshoppers in their hair she writes, "Ladies now wear Butterflys" (210). When he describes the garden of Eden as depicted in Genesis she is clearly irritated, yet she writes, "Rivers beautify Gardens to this Day" (129). This is Enlightenment universalism. She sees the present as related to the past by similarity as well as by the kind of irreversible difference stemming from events like the birth of Newton.

Guillim's treatment of natural history sometimes draws her into dialogue. She rejects one piece of bestiary lore about elephants as "false", yet apparently accepts that elephants get angry at the sight of the colour red, since she adds, "so Turkey Cocks." When Guillim writes: "The Lyon and the Lionesse do never go one and the same way, either when

15 James Cecil, third Earl of Salisbury, was obese, and was described by a contemporary as an "unhappy, self-willed man, [who] has put fair to undo himself, his relations, friends, all that had to do with him or for him" (ODNB). 
they seeke their prey or when they go to fight," she adds, "or perhaps hate like Pea cocks and Pea hens" (183). The peacock re-surfaces in Guillim later: "some write that he swalloweth up his Excrement, because he envieth man the use thereof." Montagu won't have this: "a Fib". Guillim then uses the peacock for one of his misogynist moments: when the vain peacock moults his tail he hides from sight until it grows again. "And such is the quality of many Dames, who being painted, and richly attired, cannot keep within doors, but being undressed, and in their own hew, they are loth any man should see them." Here Montagu's knowledge of peacocks (perhaps, like that of turkeys, drawn from her personal experience raising them) leads her to contradict the premiss rather than the inference: "tis the Male that is proud, beats his Wife, and destroys his Children. The Eggs are hid by ye poor Mother" (229).

As to politics, the impetus of her first annotation, rebuking grovellers to the crown, continues in later notes. Beside information about an "Abatement" which "is due to him that telleth lies, or other false tales, to his Soveraign," she writes "all courtiers should wear abatements." When Guillim observes that "Armes are honoured by the Bearers," she writes splenatically: "oftener dishonor'd". Beside "Princes will admit no fellows, to the impeachment of their Sovereignty" she writes: "Princes think ymselves above Humanity." Then, as if switching hats from moralist to politician, she adds: "in some sense true" (182).

We've seen how Montagu's comments on natural philosophy and on politics often skirt the topic of religion. When Guillim rhapsodises about "Animals wherewith God did adorne the Aire, the Waters and the Earth," she interjects wryly: "some poison it" (128). Beside a passage about the paradise of Eden she writes gnomically: "I hate ye smell of Apples" (129). She identifies "crowches" or crosses with "superstitious Times" (24). When the use of a cross in heraldry is explained as being "first bestowed on such as had performed, or at least undertaken, some service for Christ and Christian Profession," she comments: "chiefly in ye Infamous Holy War [the Crusades], thô often us'd before" (78).

She fulfils an annotator's regular function in identifying people mentioned (though for whom she is doing so remains a mystery). William Cecil is Lord Burleigh; Ravillac is the man who assassinated King Henri IV of France; Ireton is "son in law to Cromwell". Beside the Kentish name of Colepeper she writes: "I think extinct, the last the famous extravagant" (that is, inventor and hothead Thomas Colepeper, who died destitute). The Ivory family are "rich fools"; "the ancient Family of Stafford" is "a G[rea]t House still remaining. Papists." Various families are encapsulated as "thriving citizens" or "remain rich" or "remain poor presbyterians" or "eminent in Chancery" or "miserably degenerate". Sometimes elementary research in the Oxford Dictionary 
of National Biography turns up the reasons for these epithets, but some epithets remain unexplained. Many families are said to be "extinct" or "not known to me" - the latter phrase apparently descriptive and not intended as a comment on importance. Nor is a Cromwellian connection any disgrace to her: "Sir Thomas Foot Knight, Lord Mayor of London, 1651" is to her "a K[nigh]t of Olivers prhaps, a worthy man." Sir Roger L'Estrange is "then a servant of Cromwell since Author of the Observator \&c." (183) Beside the name of Sir Peter Wich, a predecessor of her husband's as Ambassador at Constantinople, some of whose family are "worthy Gentlemen and Merchants," she writes "I love commerce if Honest" (73).

She is alert to family connections of her own. Beside the entry on Evelyn (whose arms are a Griffon Passant), she writes "ye eldest Branch ended in my G. Grandfather Sr John Evelyn of West Dean Wilts" (258). The Molyneux family of Nottinghamshire are "near Neighbours to Thoresby [seat of the Pierreponts, where she grew up] \& worthy people" (85). The Barnardistons are "a real noble Descent to w[ho]m I am ally'd" (84). The Gawdys are "an old Family my G G Aunt Lady Mary Gaudy" (204). Beside William Cavendish, Marquess and Earl of Newcastle, she writes "Derbyshire old Gentry. Now Dukes, rais'd by marriage wth my G G Grandmother Eliz. Hardwick" (173). It is satisfying to know that Montagu took pride in her descent from the redoubtable woman known to history as Bess of Hardwick; I would love to know whether she also connected this family with the writer Margaret Cavendish, Duchess of Newcastle - though I suspect that Cavendish shared too much of the antique quirkiness of Guillim to recommend herself to Montagu.

Some of the annotations are scathing in their criticism. For unfathomable reasons Francis Bacon is "a learned Scoundrel justly punish'd." (121) The Grosvenor family is "a noble rich \& ancient House. Now Fools." The abatements in the Coningham family arms which suggest womanising and drinking elicits the comment: "I have known a Scotch Gentlemn of ths House. Doubtless justly acquired his Arms." On the Lisles of Wilbraham, whose family history Guillim admires, Montagu writes, "still more miserably represented \& basely rais'd by being first minister to K[ing] John" (93), the comment noting both family decline and the moral dubeity of holding office under a bad king. Alluding to the tradition of reversing or up-ending of an escutcheon to signify a traitor, she enquires, "Are the St Johns \& Sheffields revers'd?" St John is the family name of Lord Bolingbroke, who had sworn loyalty to George I and then switched to the Jacobites, but later recanted and was pardoned. Montagu particularly detested him. Beside Guillim's mention of his family arms she wrote, "How falln! How mean! How 
blotted by Cowardice \& Murder" (121). By the Sheffields she means John Sheffield, Duke of Buckingham, who was widely felt to have betrayed James II in supporting William III, and then to have repeated his treason in reverse. (He was Earl of Mulgrave, and beside that family she wrote: "concluding shamefully".) But probably the greatest crime of both Sheffield and St John in her mind was that they were patrons of her enemy Alexander Pope.

Some instances of family decline she seems to treat in a different tone, less sardonic than elegiac, with just a hint of that romantic feeling Lady Mary expressed in poetry for "Those Names which Royal Auncestry can boast / In mean Mechanic arts obscurely lost." ${ }^{16}$ Of the Hare family of Norfolk she writes "How fallen! How chang'd!" This is similar to what she said of Bolingbroke, but with "chang'd" for "mean", and with a closer echo of Milton, she suggests the fallen angel rather than the devil. ${ }^{17}$ Beside a sentence about the "Noble and hopeful Progeny" of Sir Richard Ingoldesby and his wife Elizabeth, Cromwell's daughter (in an entry which must somehow have escaped the royalist editors in 1660), she writes: "what is become of those Hopes?" (86) Beside a mention of Lord Pembroke as heir to another title she writes, "a great neglected name in a madmans Hands" (94), and one wonders whether the "great neglected name" might not in fact refer to the great literary ladies of that family: the poet Mary Sidney, Countess of Pembroke, and the family historian Lady Anne Clifford, Countess of Pembroke and Montgomery.

Montagu is alert to issues involving gender - issues which indeed she could hardly fail to note. On the page where Guillim runs through a list of first animals, secondly birds, then fishes and other "Watery Creatures: and lastly, Man," she adds the missing "Woman". When he writes that "Amongst things Sensitive, the Males are of more worthy bearing than the Females," and again a few pages later when he writes even more generally, "the Male is ever nobler than the Female," she responds with a single word: "Why?" (172). When he quotes one Albertus saying "that the Haire of Women, taken at some seasons and laid in Dung, will become very Venemous Serpents; which some hath supposed to befall that Sex, for the ancient familiarity it had at first with that accursed Serpent," she falls back once again on "Oh rare!" (211).

17 Henry Hare, third Baron Coleraine, separated from his wife and had several mistresses, with one of whom he entered into a form of marriage. He and his grandfather were antiquaries. 
At one point Guillim writes about the arms borne by a second brother if his elder brother has no sons but only daughters. In one particular case it was approved for such a brother to use the "Labell of the Heire apparent" because he would inherit in case "the Issue of his Neeces should fail," and this precedent has been followed since then. This encroaching uncle seems to verge on the wicked uncle of fairy story - is the issue of nieces more likely to fail than that of nephews? - but what Montagu writes is: "poor Females always change for ye worse. Fashions our ruine" (33).

Apparently this particular inequity left Montagu no recourse but that of facing up to unpalatable fact; but when Guillim says that at marriage, women are "separated and divided from the Family whereof they are descended, in as much as when they are once married, they doe lose their own surname, and doe receive their denomination from the Family whereof their Husbands are descended," Montagu writes, "Priestly invention to have all poor Girls in their Power." From here Guillim moves on to the issue of women's coat-armour (the unique form of which is inherited from their fathers but does not descend to their children, since women do not go to war and are usually passed over as heirs in favour of brothers or brothers' sons). Here Montagu adds not a bitter comment but a positive statement: "different Laws in Germany vide vita Agricola" (40). ${ }^{18}$

At least once Guillim pays tribute to women. On the same page where he has written, "Gores and likewise Gussets are things in use among women, especially Sempsters, \& therefore are fit notes of Cowards," he goes on to acknowledge: "many of which sex are so far from the stain of Cowardize, as they will not turn their backs to men of greater valour; but like the valiant Penthesilea [etc]." Finding a philosophical opinion with which she can agree, Montagu is quick to do so: "Women can give ye highest marks of Honor \& lowest marks of Infamy. This is certain Truth" (45).

Occasionally Lady Mary's tone is hard to gauge. When Guillim advises "all Gentlewomen to look on Glasses; that so, if they saw themselves beautifull, they might be stirred up to make their minds as faire by vertue as their faces were by nature," she writes with sarcasm: "I dare swear well obey'd." Well, of course not, but does she find such sexist didacticism acceptable or not? "And those that are proud of their beauty," he continues, "should consider, that their own hue is as brittle as the Glasse wherein they see it; and that they carry on their shoulders 
nothing but a Skull wrapt in skinne, which one day will be loathsome to be looked on." Montagu's comment - "many forget that" - suggests that she is not blandly agreeing but is being sardonic about this Jacobean morality.

A surprising quality in her annotation is her partiality to sexual innuendo. When Guillim writes about fesses she glosses this as "back side" and adds "delicate seats for Honor!" (41). At the first mention of the bend sinister she writes, "Hum Hum mum" (59). At a mention of "the Reward of a Gentlewoman for service by her done to the Prince" she glosses: "Concubines" (76). Beside an explanation of the different ways of bearing ordinaries, "One upon another / One besides another," she writes "room for Jokes" (87).

The rag-bag of information which she brings to her marginalia includes a couple of doggerel rhymes. Sir Roger Burgoine, she writes, "holds his Land by this old Rhime. I John of Gaunt do give \& grant to John of Burgoine \& all of his line ye manors of Potten \& Slotten \& may they endure to his children fall sure till ye Earth it selfe be rotten." Her "Slotten" is quite clear, though the version quoted in Google says - I'm sure correctly - Sutton. The other rhyme she merely refers to. Guillim writes that frogs on occasion "doe rejoyce, and doe testify their joy by singing after their manner;" she notes "see Dr Popes Ballad B[isho]p Ward," alluding to a lovely spoof by Walter Pope (collected by John Nichols in 1782) in which one of the reasons cited for building Salisbury Cathedral in the water-meadows is to "hear the sweet fishes sing" (205).

In her annotations Montagu cites, or alludes to a wide variety of writing including Tacitus, Milton and Newton. The "name of Jones" makes her write "Tom Jones" in the margin. (I doubt it counts as a literary reference when she writes beside the name of Wild: "extinct or poor perhaps related to ye famous Theif Taker"). Her allusions to women writers tend to be indirect, even doubtful, but I suspect there are many of them. Beside the family of Dering she writes: "I think extinct in $\mathrm{Sr}$ Edwd Deering see Mrs Philips poems." Beside Heneage of Lincolnshire she writes, "lost in Finch," - thinking perhaps of that Heneage Finch whose wife was Anne Finch, the poet (141). She apparently makes an oblique reference to the greatness of Mary Sidney, Countess of Pembroke, and she at least possibly alludes to Margaret Cavendish, Duchess of Newcastle. And her single expression of admiration for a historical figure goes to a woman: beside the name of Queen Elizabeth she writes: "realy great, if great \& Human can agree" (78).

The great paradox of Lady Mary's annotations is the manner in which alongside all the evidence of opposition to patriarchy is expressed a deep family pride. From a woman so clear-eyed about the 
disregard of great families for their female members, such pride verges on the pathetic. The Pierreponts are "my Family" — but of course Lady Mary has long ceased to bear their name, and their representative is her disappointing nephew. The last of the Evelyns, in her naming, was her great-grandfather Sir John, not her indomitable grandmother Elizabeth Pierrepont née Evelyn. In such moments of filial piety, Lady Mary, because she is in dialogue with a book of heraldry, inevitably becomes a kind of traitor to her sex. Thank heavens for Queen Elizabeth, who allows her the rare luxury of feeling both reverence for the past and pride in her gender.

Literary identity, it seems, is like DNA, occupying every fragment of writing. In an individual in whom that identity is strong, even desultory and purposeless writing destined for an inimical environment is infused with character. It seems almost impossible that Lady Mary had any specific reader in mind as she wrote these fragments, let alone that she could have foreseen how admirers of Montagu the author would relish their characteristic flavour. The annotations show her the same person as she appears in her poems and letters and fiction: a woman shaped by an antique world of male privilege and pride of birth, but testifying against gender inequity and unscientific superstition. They show her as a "character", a crusty old lady impatient of folly and ignorance, a critic who cannot read without commenting. Yet they demonstrate also how ordinary an activity was writing by the middle of the eighteenth century, how literacy inflected every pastime, how easy it was for a reader to morph into a writer.

ISOBEL GRUNDY

University of Alberta 